WIELKIE TEMATY KULTURY W LITERATURACH SKOWIAŃSKICH

Slavica Wratislaviensia CLXVIII • Wrocław 2019•AUWr No 3875

DOI: 10.19195/0137-1150.168.13

Data przesłania artykułu: 18.09.2017

Data akceptacji artykułu: 7.01.2018

\title{
ALLA DEMCHENKO
}

Херсонський державний університет, Ukraina

\section{Міфопоетична танатологія у ліриці Сергія Жадана}

3 найдавніших часів ставлення до феномену смерті має амбівалентний характер. 3 одного боку, людина боїться смерті, а $з$ іншого - намагається пізнати їі таємниці, заглянути по той бік неіснування.

Мотиви буття та смерті на сьогодні є особливо актуальними в контексті історії культури, філософії, релігієзнавства, літератури. Науковці продовжують дослідження феномену смерті, проводять історично-порівняльний аналіз різних культур і релігій. Танатологічна тема не втрачає своєї актуальності і в добу постмодернізму.

Сергій Жадан вже давно заслужено займає чільне місце в сучасній літературі як в Україні, так і за ï межами. Увага прикута до поезії, прози, музичної діяльності митця, його художні твори перекладені багатьма мовами, удостоєні високими преміями, покладені на музику, екранізовані. Оригінальні, актуальні, філософські поетичні тексти Жадана експлікують проблеми українського буття на західноєвропейський грунт, розширюючи кордони суто національного красного письменства до рівня світової культури. Міф, символічні образи, народні традиції та вірування відіграють важливу роль у сучасних художніх творах поета, акумулюють традиційне і нове, ретранслюють естетичні преференції української літератури світовому культурному загалу та свідчать про еволюцію авторської свідомості.

Аналіз лірики Жадана репрезентовано у наукових студіях вітчизняних літературознавців. Зокрема, Богдан Пастух та Ольга Шаф акцентують увагу на урбаністичних мотивах ${ }^{1}$, Лариса Литвин та Шаф розглядають інтер-

1 Б. Пастух, Міські пасторалі Сергія Жадана), Bukvoid.com, http://bukvoid.com.ua/reviews/books/2012/03/07/120646.html [дата доступу: 11.03.2017]; О. Шаф, Топос міста в поезії Сергія Жадана як маскулінізаиія світу, http://dspace.nbuv.gov.ua/handle/123456789/38100 [дата доступу: 11.03.2017].

Slavica Wratislaviensia 168, 2019

(C) for this edition by CNS 
претацію біблійних образів та мотивів у поетичних текстах автора ${ }^{2}$ Юлія Вишницькадосліджує варіації міфосценарію початку у збірках поета ${ }^{3}$, творчий портрет Жадана подають Лариса Березовчук, Анна Біла та багато інших науковців. Іван Дзюба у книзі Чорний романтик Сергій Жадан вказує на дивовижну асоціативність та світове значення поезій митця ${ }^{4}$. Ірина Борисюк у статті Метафори смерті в поезї С. Жадана розкриває глибоку символіку образів дороги, раю, води, риби, що пов'язані з ідеєю смерті ${ }^{5}$. Об`єктом їі дослідження постали збірки Ефіопія (2009) та Лілі Марлен (2011). Дослідниця доходить висновку, що:

підгрунтям для Жаданових метафор смерті є як християнська, так і міфологічна образність. Характерно, що смерть у ліриці Сергія Жадана постає в упізнаваних, знайомих образах, вписуючись у звичну картину світу і стаючи її невід’ємною частиною ${ }^{6}$.

Однак міфосвіт поетичної танатології цього автора ще потребує глибокого і всебічного дослідження, чим і визначається актуальність нашої теми.

Метою статті є осмислення міфопоетичної танатології збірок Жадана Життя Марії (2015) і Тамплієри (2016), виявлення спектру індивідуально-авторської інтерпретації мотиву смерті через художню систему образів та мотивів, створених автором.

Аналізуючи лірику Сергія Жадана кінця 90-х та перших десятиліть 2000-х років, Ольга Шаф у статті про топос міста цілком справедливо констатує: „Смерть у поезіях Жадана описана емоційно нейтрально, констатативно, часом з іронічною легкістю (можливо, й удаваною)”" . Далі дослідниця підсумовує, що „мертвотна атмосфера міста у творах митця і $є$ втіленням летального, що проектується на весь світ, позбавляючи його

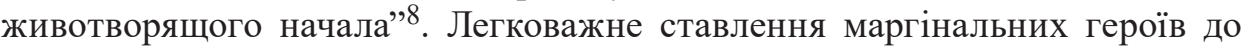
життя нівелює сакральне уявлення про смерть, натомість на перший план виступає постмодерністська стилістика з їі основними ознаками.

Поет по-різному осмислює смерть, світовідчуття автора еволюціонує від саркастичного підходу в художній реалізації категорій життя/смерть до національно детермінованих уявлень про цінність людського життя, які

2 Л. Литвин, Збірка С. Жадана „Життя Марії”: Марійний дискурс, „Молодий вчений” 12 (39), 2016, с. 366-370; О. Шаф, Біблійний дискурс у творчості Сергія Жадана: кониептуальність та функціональність), „Український смисл” 1, 2012, https://ukrsense.dp.ua/index. php/USENSE/article/view/4 [дата доступу: 05.04.2017].

3 Ю. Вишницька, Текстова поліваріативність міфологічного сценарію початку як реалізачія космогонічних та антропогонічних міфів (на матеріалі поезї Сергія Жадана), „Літературний процес: методологія, імена, тенденціі” 4, 2014, с. 3-9.

4 I. Дзюба, Чорний романтик Сергій Жадан, Київ 2017

5 І. Борисюк, Метафори смерті в поезії Сергія Жадана, „Літературознавчі студії” 43, 2015, c. 93-99, http://nbuv.gov.ua/UJRN/Lits_2015_43(1)__14 [дата доступу: 05.04.2017].

6 I. Борисюк, Метафори смерті...

7 О. Шаф, Топос міста в поезї...

8 Там само. 
з огляду на трагічні події в Україні переходять у площину апокаліптичних візій. Образ смерті в ранній поезії Жадана постає амбівалентним, а відтак — вона не сприймається негативно, бо у героїв відсутній страх. Автор артикулює мортальний мотив через абсурдний світ, що поглиблює екзистенційні смисли. Доволі переконливо про це пише Ірина Борисюк:

Смерть у ліриці Жадана - така ж фатальна, безпричинна й неминуча, як у фольклорній баладі. Смерть $є$ одним із найчастотніших мотивів у його поезії, й саме тому поет вибудовує власну символіку, метафорику й навіть міфологію смерті 9 .

Таким чином, у ранній ліриці Жадана на перший план виступають мотив любові та мотив смерті.

Досліджуючи поетичні тексти зі збірок Життя Марї (2015) і Тамплієри (2016), ми відзначаємо зміну вектору авторського бачення. Про віднайдення глибинних смислів та інтерпретації біблійних образів, які символізують національне відродження, надію на гармонійне і справедливе перетворення світу на шляху „біблійного виходу із неволі” для сучасної України, йдеться у статті Алли Демченко Національний міфосвіт збірки Сергія Жадана „Життя Марї,"10.

У названих двох збірках спостерігаємо збільшення емоційного наповнення танатологічного мотиву віршів. Жадан уже не обмежується зображенням природної чи випадкової смерті, абсурдної поведінки самогубців чи загибелі маргіналів.

Лірика митця набуває нової риторики, а мотив смерті - мілітаризоване обличчя. Прикметно, що збірка Тамплієри самою вже назвою спонукає до проведення історичних паралелей. Відомо, що тамплієрами називали середньовічних безстрашних монахів-воїнів. Лицарський орден тамплієрів поєднував чернецтво і військову справу. Обкладинка книжки Жадана виконана у дуже стриманій стилістиці і нагадує вбрання тамплієрів, які виділялися серед інших воїнів білим одягом із червоним хрестом на грудях або на серці. А суперобкладинка містить ілюстрацію, виконану сучасним художником Олександром Ройтбурдом, одним із засновників українського постмодернізму.

Тетяна Трофименко у рецензії на збірку Тамплієри вказує:

Жадан уже не хуліганить: хрестові походи стали для нього не джерелом інтертекстуальної гри, а моторошною дійсністю спалених міст. [...] постать священика - тамплієра Донбасу - суто умовна. Здається, він не дуже розуміє - любити цих людей чи ненавидіти, $€$ шанс на їхнє спасіння чи ні. Позірно християнський сенс, що

9 І. Борисюк, Метафори смерті..., с. 93-99.

10 А. Демченко, Начіональний міфосвіт збірки Сергія Жадана „Життя Марії”, [в:] Щорічний науковий збірник Сьомої міжнародної науково-практичної Інтернет-конферениії з украйністики „Діалог мов - діалог культур. Украйна і світ”, Мюнхен 2016, с. 349-356. 
його автор вкладає в біблійні образи та мотиви, химерно поєднується зі шматками реальних кадрів із поїздок у сіру зону та на передову ${ }^{11}$.

Мотиви смерті, холоду, порожнечі, болю, смутку і постійної самотності у світі, сприйняття світу як тісної, темної самотньої могили, в’язниці або ями, думки про втрату рідного дому, міста, маленької батьківщини звучать у поетичних текстах обох збірок, поступово посилюючись у Тамплієрах, генерують їх образність.

Зокрема, книга Життя Марії оперує міфологемами дому, птаха, образами біженців, дезертирів, символікою чорного та сірого кольорів, антитезою любов-смерть. Названі символи, образи, мотиви мають значні конотації з темою смерті. Крім того, смерті з її похідними константами розлуки з рідними і близькими та філософським розумінням плину часу, минущості життя протиставляється любов і пам'ять, які не підвладні смерті:

Діти, що народяться під такими зірками

і яких називатимуть іменами загиблих,

говорячи зі злодіями та ворогами,

вкладатимуть мудрість у кожен свій видих.

Так, ніби до них не було смерті, так, ніби за ними немає люті.

Будуть упевнені та уперті,

будуть пам'ятати всі речі забуті. [...]

Тобі це вдасться, спробуй, навчи їх, любити, вірити і пам'ятати.

Пам'ятати все, що несли з собою, чорну траву під ламкими снігами, небо над випаленою головою,

землю під втомленими ногами ${ }^{12}$.

У збірці Життя Марії актуалізується інтертекстуальність, притаманна поетичним текстам Жадана. За допомогою алюзії автор оприявнює біблійне пророцтво, чим посилює апокаліптичну картину смерті:

Пам'ятаєте, що сказано в пророків про біль і терпіння, про птахів, які падають на міста, мов каміння?

Ось саме тоді й починаються, власне, втрати.

В кінці - там взагалі погано, не буду навіть розповідати.

Яка між нами різниця? Як між приголосними й голосними.

Всі готові сприймати смерть, якщо це буде не з ними.

Ніхто й ніколи в цьому житті не омине розплати.

Я завжди говорю про це своїм, коли не маю чого сказати ${ }^{13}$.

11 Т. Трофименко, Тамплісри Донбасу. Рещеенія, https://tsn.ua/blogi/themes/books/tampliyeridonbasu-744922.html [дата доступу: 12.03.2017].

12 С. Жадан, Життя Марії, Чернівці 2015, с. 23.

13 Там само, с. 13.

Slavica Wratislaviensia 168, 2019

(C) for this edition by CNS 
Для Жадана одним із концептуальних образів виступає дім, представлений у збірці Життя Марії і Тамплієри у різноманітних модифікаціях. Топос дому виконує не лише охоронну чи захисну функцію, але й духовну, сакральну та екзистенційну тощо.

У поезіях зі збірок Життя Марії та Тамплієри через образ дому есплікується екзистенціальний варіант мотиву смерті: більшість картин трагічні, пов'язані з війною. У вірші Як ми будували свої доми? (Тамплієри) основним художнім прийомом виступає контраст:

Як ми будували свої доми?

Коли стоїш під небесами зими,

і небеса розвертаються й відпливають геть,

розумієш, що жити потрібно там, де тебе не лякає смерть.

Будуй стіни з водоростей і трави,

рий вовчі ями й рови.

Звикай жити разом з усіма день при дні.

Батьківщина - це там, де тебе розуміють, коли ти говориш вві сні ${ }^{14}$.

Поступово танатичні смисли проступають і в образі міста, простір якого несе ознаки смерті. У поетичних збірках Життя Марї і Тамплієри розкривається сучасна трагедія країни, спричинена війною:

Наше місто було з каменю та заліза.

У кожного з нас тепер у руці дорожня валіза.

У кожній валізі попіл, зібраний під прицілом.

Тепер навіть у наших снах пахне горілим ${ }^{15}$.

Образ спаленої церкви репрезентує опозицію сакральне/профанне, життя/смерть. Модель танатопростору у Жадана передається через зіставлення світу за межами зруйнованого міста — живого, відкритого та простору замкненого. Танатологічні мотиви у віршах митця представлені локусами могил. Поклоніння могилам предків - запорука національної пам'яті. Мірче Еліаде зауважує:

Те, що ми називаємо життям і смертю, - просто два моменти в цілісному існуванні Матері-Землі: життя — це вихід з утроби Землі, відділення від неї, а смерть — повернення „додому”. Часто люди виявляють бажання бути похованими на батьківщині, що $є$ всього лише профанною формою цієї містичної любові до своєї власної Землі, потребою повернутися до рідної домівки ${ }^{16}$.

Увиразнює танатопоетику збірки Тамплієри образ змій у місті, що надає хронотопу трагічного і водночас моторошного забарвлення:

14 С. Жадан, Тамплієри..., с. 8.

15 С. Жадан, Життя Марї..., с. 10.

16 М. Элиаде, Очерки сравнительного религиеведения, пер. В. Рокитянский, Москва 1999 , c. 241 
Міста будували з сонця і глини, замішували їх на вірі й надії.

Але приходить літо в холодні долини, і на камінні гріються змії.

Змії заповзають в наші будинки, змії сплять на ламких простирадлах, обживають кишені й армійські ботинки, лежать по коморах і сухих підвалах

Від червня горить, не згасаючи, спека, і змії вичікують під подушками, ховаються в кухнях та бібліотеках, звиваються за віршами та словниками ${ }^{17}$.

У християнстві змія - амбівалентний символ: це і Христос, піднесений на Дереві Життя як викупна жертва, і диявол у його хтонічній іпостаci, що уособлює зло, яке людина повинна в собі подолати. Образ змії тут наділяється демонічними якостями та виступає символом смерті, оскільки трактується автором як підступний і небезпечний ворог, який захопив рідний дім. Тому глибокого значення набуває образ змієлова, семантику якого автор адаптував під реалії сучасних в Україні подій:

Доброго полювання тобі, змієлове,

твердої руки й гострого ока.

Кожен із нас тебе знає й кличе,

і доки діти бояться заснути,

доброї роботи тобі, чоловіче,

хай менше довкола буде отрути.

Знайди бодай якесь виправда́ння

цьому місту із тисячею криївок.

Хай повертаються після вигнання

вагітні жінки до своїх домівок ${ }^{18}$.

Екзистенційні мотиви у поезіях Жадана репрезентовані через міфологему смерті, яка увиразнюється за допомогою образів дому, міста, церкви, могили, змій тощо. Від ранньої лірики і до останніх поетичних збірок Життя Марії $і$ Тамплієри смерть виступає лейтмотивом творів Жадана, спостерігається зміщення акцентів від сакрального розуміння смерті до профанного, артикулюючи сучасні події в Україні, поглиблюючи філософське звучання текстів.

17 С. Жадан, Тамплісри..., с. 12.

18 Там само, с. 13.

Slavica Wratislaviensia 168, 2019

(C) for this edition by CNS 


\section{Бібліографія}

Borysjuk I., Metafory smerti v poezii' Sergija Zhadana, „Literaturoznavchi studii'”, http://nbuv.gov. ua/UJRN/Lits_2015_43(1)__14.

Demchenko A., Nacional'nyj mifosvit zbirky Sergija Zhadana „Zhyttja Marii'”, [v:] Shhorichnyj naukovyj zbirnyk S'omoi' mizhnarodnoi' naukovo-praktychnoi' Internet-konferencii' z ukrai'nistyky „Dialog mov - dialog kul'tur. Ukrai'na i svit”, Mjunhen 2016.

Dzjuba I., Chornyj romantyk Sergij Zhadan, Kyi'v 2017.

Eliade M., Ocherky sravnytel'nogo relygyevedenyja, per. V. Rokitjanskij, Moskva 1999.

Lytvyn L., Zbirka S. Zhadana „Zhyttja Marii'”: Marijnyj dyskurs, „Molodyj vchenyj” 12 (39), 2016.

Pastuh B., Mis'ki pastorali Sergija Zhadana, Bukvoid.com, http://bukvoid.com.ua/reviews/ books/2012/03/07/120646.html.

Shaf O., Biblijnyj dyskurs u tvorchosti Sergija Zhadana: konceptual'nist' ta funkcional'nist'), „Ukrai'ns'kyj smysl” 1, 2012, https://ukrsense.dp.ua/index.php/USENSE/article/view/4.

Shaf O., Topos mista v poezii' Sergija Zhadana jak maskulinizacija svitu, http://dspace.nbuv.gov.ua/ handle/123456789/38100.

Trofymenko T., Tamplijery Donbasu. Recenzija, https://sn.ua/blogi/themes/books/tampliyeri-donbasu-744922.html.

Vyshnyc'ka Ju., Tekstova polivariatyvnist' mifologichnogo scenariju pochatku jak realizacija kosmogonichny ta antropogonichnyh mifiv (na materiali poezii' Sergija Zhadana), „Literaturnyj proces: metodologija, imena, tendencii"' 4, 2014.

Zhadan S., Tamplijery, Chernivci 2016.

Zhadan S., Zhyttja Marii', Chernivci 2015.

\section{Mythopoetic thanatology in Serhiy Zhadan's poetry}

\section{Summary}

The article deals with the mythologem of death in Serhiy Zhadan's poetry. The author argues that both traditional Ukrainian culture and the universal symbols of human consciousness are sources of thanatological images in Zhadan's collections Life of Mariia (2015) and Knights of the Temple (2016). The author focuses on the implementation of thanatological themes through the motifs of family, memory, oblivion, loss, and return. Moreover, she claims that Zhadan uses the mythical semantics of the images of primordial elements, house, serpent, and bird to demonstrate the spatial metaphor of the lost homeland.

Keywords: mythologem, mythology, thanatological images, archetypal image 


\section{Мифопоэтическая танатология в лирике Сергея Жадана}

Резюме

В статье исследуется мифологема смерти в поэзии Сергея Жадана. Выяснено, что танатологические образы, представленные в сборниках Жизнь Марии (2015) и Тамплиеры (2016), базируются на украинской традиционной культуре и интерпретации образов-символов общечеловеческого сознания. Сосредоточено внимание на реализации танатологического мотива через мотив родовой памяти, забвения, потери, возвращения. Раскрывается мифосемантика образов первостихий, дома, змея, птицы, которые представляют в поэтических текстах пространственную метафору утерянной малой родины.

Ключевые слова: мифологема, мифомир, танатологические образы, архетипический образ 